\title{
Literature Review: The Implementation of Infection Prevention and Control Programs On the Medical Staffs
}

\begin{tabular}{l}
\hline I N D E X I N G \\
\hline Keywords: \\
Implementation; \\
IPC program
\end{tabular}

Gilang Indhira Mustika ${ }^{1}$, Kusbaryanto ${ }^{2}$

${ }^{1}$ Correspondence Author: indhiragilang@gmail.com

1,2Magister Administrasi Rumah Sakit, Universitas Muhammadiyah Yogyakarta, Yogyakarta, Indonesia

Kata kunci:

Implementasi; Program $P P I$

\begin{abstract}
A B S T R A C T
The aim of this systematic review is to analyze the implementation of infection prevention and control programs in medical personnel. The research phase begins with the formulation of a research question (RQ) and data collection begins with a search for research with qualitative methods at PubMed, Science Direct, ProQuest, GARUDA and Google Scholar on "infection prevention and control", "IPC management", and "the implementation process. IPC "for health personnel, published between January 2015 and June 2020. A total of 106 publications were taken, synthesized article $(n=14)$. Based on the mapping results of 14 articles regarding the implementation of infection prevention and control programs for medical personnel, they are grouped into research focus and paper type categories. Gaps were identified related to lack of knowledge, awareness and commitment to the importance of IPC during health service delivery. Management needs to provide support with training, funding for the IPC program so that it supports infrastructure. Human resource factors and other supporting factors contribute to the implementation of IPC so as to reduce the incidence of infection.
\end{abstract}

Tujuan dari tinjauan sistematis ini adalah untuk menganalisis pelaksanaan program pencegahan dan pengendalian infeksi pada tenaga medis. Tahap penelitian diawali dengan formulasi research question (RQ) dan dilakukan pengumpulan data dimulai dengan penelusuran penelitian dengan metode kualitatif pada Pubmed, Science direct, Proquest, GARUDA dan Google scholar tentang "pencegahan dan pengendalian infeksi", "manajemen IPC", dan "proses pelaksanaan IPC" pada tenaga kesehatan, diterbitkan antara Januari 2015 dan Juni 2020. Sebanyak 106 publikasi diambil, dilakukan screening, artikel yang disintesis $(n=14)$. Berdasarkan hasil pemetaan dari 14 artikel mengenai penerapan program pencegahan dan pengendalian infeksi pada tenaga medis dikelompokan dengan kategori research focus dan paper type. Kesenjangan terjadi teridentifikasi terkait kurangnya pengetahuan, kesadaran dan komitmen akan pentingnya IPC selama memberikan layanan kesehatan. Manajemen perlu memberikan dukungan dengan adanya pelatihan, pendanaan untuk program IPC sehingga menunjang sarana prasarana. Faktor sumber daya manusia dan faktor penunjang lainnya memberikan kontribusi dalam penerapan IPC sehingga mampu menurunkan kejadian infeksi.

(C)2021JMMR. All rights reserved

\section{INTRODUCTION}

Nosocomial infections or also often referred to as Hospital Acquired Infection (HAI's) is a major problem faced by hospitals, especially in poor and developing countries (Damanik et al., 2012). Infection that is acquired in the hospital is called nosocomial infection, which is an infection that affects a person and the infection is caused by the influence of the hospital environment. Nosocomial infection occurs at least $3 \times 24$ hours from admission, and is not a continuation of the previous disease (Nugraheni et al., 2012).

Nosocomial infection is a worldwide problem, especially in poor and developing countries because infectious diseases are still the main cause of health problems. A study conducted by WHO shows that about $8.7 \%$ of 55 hospitals from 14 countries spread across Europe, the Middle East, and Southeast Asia and the Pacific have nosocomial infections. In Southeast Asia, the 
incidence of nosocomial infections is as much as 10\% (Nugraheni et al., 2012). In a study in 11 hospitals in DKI Jakarta Province in 2004, it was shown that $9.8 \%$ of inpatients at the hospital got new infections during their stay at the hospital (Damanik et al., 2012). Another study states that in Indonesia in 2006 the percentage of nosocomial infections in Lampung Province was 4.3\%, Jambi 2.8\%, DKI Jakarta 0.9\%, West Java 2.2\%, Central Java 0.5\%, and Yogyakarta $0.8 \%$ (Pratami et al., 2013). The incidence of nosocomial infections in educational hospitals is also quite high, namely 6-16\% with an average of 9.8\% in 2010 (Nugraheni et al., 2012).

Prevention of infection is essential. One of the preventive measures is terminating the transmission. The implementation of correct techniques and procedures by officers is the most important behavior in infection prevention efforts (Rosaliya et al., 2012). Control of nosocomial infections can be done with a combination of several interventions, namely knowledge of standard precautions, rational use of antibiotics, and the application of standard precautions itself (De Carvalho Nagliate et al., 2013). Standard precautions or also often referred to as Standard Precautions is an effort that aims to reduce the risk of transmission of diseases or pathogens that are transmitted through blood and other body fluids, whether the source is known or unknown (WHO, 2007).

The study conducted by Fayaz et al., Showed a low level of universal precautions among health workers in Kabul; only 19.0\% of respondents fully practiced with all 11 items of Universal Precautions. Health workers in Kabul do not always change gloves when treating different patients, and $40.7 \%$ of health workers do not always wear eye shields / goggles when they are splashed with discharge blood (Fayaz et al., 2015). In the study by Beyamo et al., It was found that the majority of health care workers did not adhere to standard preventive practices $(35 \%)$ (Beyamo et al., 2019).

Human resource factor research in India is a major obstacle and facilitator for infection control in hospitals. The main barriers include the high turnover rate of nursing staff and limited language competence (Barker et al., 2017). Carelessness of health care workers is the top cited factor contributing to the cause of the outbreak (65.07\% of the total group) (Rabaan et al., 2017). Research studies in Nigeria demonstrate knowledge and awareness of control infection among health workers in the ICU is good but the practice is not good (Adegboye et al., 2018).

Funding factors are also key in implementing IPC. A study conducted at a hospital in Indonesia found that the funds for the implementation of infection prevention and control were insufficient (Ramayanti et al., 2019). Economic challenges in the use of infection prevention and control programs, include variable utility in infection prevention and control, lack of controlled trials, and difficulties in modeling infectious diseases in general, which require a lot of funds to support the smooth running of the IPC program (Rennert-May et al., 2018).

Studies conducted in several hospitals in Indonesia show that many hospitals are not ready to carry out IPC, especially in facilities and infrastructure for sterilization, clean water and sewage treatment, especially in class C and D hospitals (Herman \& Handayani, 2017). Lack of management support for IPC support programs and facilities has resulted in less optimal IPC in one Malng hospital (Kartika S et al., 2015). Hospital infrastructure and design are the main factors that contribute to the spread of infection in hospitals (54.20\%) (Rabaan et al., 2017).

The description of the supervisory duties by IPCN has gone well, while the supervisory duties by IPCLN have not been optimal due to the many tasks and responsibilities that must be carried out and the absence of special incentives or benefits given to IPCLN (Ginting et al., 2018). To maximize the prevention and control of HCAI and MDRO in Europe, surveillance should be further increased by targeting infections related to relevant health services. The role of feedback should be explored in more detail (Hansen et al., 2018). Transmission of infection can 
be avoided by using infection control practices. A well-managed surveillance methodology is required based on CDC guidelines (Khan et al., 2015).

Massinga's research shows that although health workers take precautions to prevent infection, they do not achieve full compliance with universal precautions. Qualitative data shows that reasons for non-compliance include lack of knowledge about universal precautions, communication factors, resources, including maintenance of equipment, lack of supply and lack of human resources and attitudes of health workers (Massinga, 2016). Research by Birgand et al., contextual aspects such as the relationship between medical personnel and resources and behavior including professional background or experience are elements that contribute to the successful implementation of infection control and prevention measures. Behavioral change techniques providing goal setting, feedback and action planning have been shown to be effective in mobilizing medical personnel and may be the key to triggering social movement implementation (Birgand et al., 2015).

Based on the above background, the researchers are interested in analyzing the implementation of prevention and control of further infection in an effort to reduce the risk of infection in the hospital. This study is expected to complement theoretical concepts of patient safety, particularly in infection prevention and control, so as to help improve understanding of patient safety. This study can be used as a basis for preparing future activities and strategic planning for infection reduction in hospitals because it is known that several aspects affect the implementation of infection control and prevention in hospitals.

\section{RESEARCH METHOD}

This type of research is literature research, which is research that critically reviews or reviews the knowledge, ideas or findings contained in the academic-oriented literature, and formulates its theoretical and methodological contributions to certain topics (Sugiyono, 2010). The literature review design used in this research is systematic literature review or often abbreviated as SLR or in Indonesian it is called a systematic literature review is a literature review method that identifies, assesses, and interprets all findings on a research topic, to answer research questionswhich has been determined previously (Kitchenham \& Charters, 2007). The RQ formulation must be based on elements in the framework, namely SPIDER (Sample, Phenomenom of Interest, Design, Evaluation, Research Type).

This research question concentrates on the topic of implementing infection prevention and control programs. The data collection stage began with a search on Pubmed, Science direct, Proquest, GARUDA and Google scholar totaling 106 with the keywords "infection prevention and control", "IPC management", and "IPC implementation process" for health workers. The inclusion criteria set are publications published from 2015-2020, articles published in Indonesian and English and publications through well-known journals and proceedings of international scientific meetings, and qualitative method research. While the exclusion criteria were research in the form of a thesis / thesis monograph, duplicate research, and publications for more than 5 years.

After the data was collected, a maipcng was carried out based on the research type and research focus. Mapped research data is displayed for later discussion in the discussion. Then the researcher arranged a discussion based on the results of the SLR maipcng as discussion data. The final step of this research is to make recommendations and conclusions. 


\section{RESEARCH RESULT}

Tabel 1. Summary of Literature Review

\begin{tabular}{|c|c|c|c|c|c|c|}
\hline No & Title/ Author/ Year & Research Purposes & Method/ Design & $\begin{array}{c}\text { Participants / } \\
\text { Number of } \\
\text { Samples }\end{array}$ & $\begin{array}{c}\text { Data } \\
\text { Collection }\end{array}$ & Result \\
\hline 1. & $\begin{array}{l}\text { Implementation of Infection } \\
\text { Prevention and Control } \\
\text { Programs at the Royal Prima } \\
\text { Public Hospital in 2018 } \\
\text { (Ginting et al., 2018) }\end{array}$ & $\begin{array}{l}\text { Prevent and control } \\
\text { infection }\end{array}$ & $\begin{array}{l}\text { Qualitative, } \\
\text { descriptive analysis } \\
\text { approach }\end{array}$ & $\begin{array}{l}\text { Director with the } \\
\text { Structutal } \\
\text { Hospital ranks }\end{array}$ & Interview & $\begin{array}{l}\text { The implementation of the } \\
\text { infection prevention and } \\
\text { control program at the Royal } \\
\text { Prima Hospital has been going } \\
\text { well. }\end{array}$ \\
\hline 2. & $\begin{array}{l}\text { Analysis of the } \\
\text { Implementation of the } \\
\text { Nosocomial Infection } \\
\text { Prevention and Control } \\
\text { Program in West Pasaman } \\
\text { Regional Hospital } \\
\text { (Accreditation Standard } \\
\text { Version 2012) } \\
\text { (Ramayanti et al., 2019) }\end{array}$ & $\begin{array}{l}\text { Analyze the } \\
\text { implementation of } \\
\text { the IPC program }\end{array}$ & $\begin{array}{l}\text { Descriptive with a } \\
\text { qualitative approach. }\end{array}$ & $\begin{array}{l}\text { Director, chair of } \\
\text { the hospital } \\
\text { infection } \\
\text { prevention and } \\
\text { control } \\
\text { committee, } \\
\text { IPCO and IPCN. } \\
\text { The informant in } \\
\text { the FGD was } \\
\text { IPCLN. }\end{array}$ & $\begin{array}{l}\text { Interview, } \\
\text { FGD, } \\
\text { document } \\
\text { review and } \\
\text { observation }\end{array}$ & $\begin{array}{l}\text { Some input components are } \\
\text { not in accordance with } \\
\text { standards, the implementation } \\
\text { of IPC is not optimal and } \\
\text { consistent. The } \\
\text { implementation of the IPC } \\
\text { program has not been achieved } \\
\text { according to standards. }\end{array}$ \\
\hline 3. & $\begin{array}{l}\text { Description of the } \\
\text { Implementation of Infection } \\
\text { Prevention and Control } \\
\text { Programs at X City Y } \\
\text { General Hospital } \\
\text { (Rismayanti, 2019) }\end{array}$ & $\begin{array}{l}\text { See an overview of the } \\
\text { implementation of } \\
\text { infection prevention } \\
\text { and control programs } \\
\text { at X General } \\
\text { Hospital. }\end{array}$ & Qualitative & $\begin{array}{l}\text { IPCN, IPCLN } \\
\text { and, Head of the } \\
\text { Room }\end{array}$ & Interview & $\begin{array}{l}\text { Infections that occur in } \\
\text { hospitals can not only be } \\
\text { controlled but can also be } \\
\text { prevented by taking steps in } \\
\text { accordance with applicable } \\
\text { procedures and guidelines. }\end{array}$ \\
\hline 4. & $\begin{array}{l}\text { Analysis of the } \\
\text { Implementation of the } \\
\text { Prevention and Control of } \\
\text { Nosocomial Infection in the } \\
\text { ICU at the Labuang Baji } \\
\text { Makassar Hospital (Syahrir } \\
\text { et al., 2018) }\end{array}$ & $\begin{array}{l}\text { Knowing the } \\
\text { description of } \\
\text { prevention and } \\
\text { control of } \\
\text { Nosocomial Infection } \\
\text { in the Intensive Care } \\
\text { Unit of the Labuang }\end{array}$ & $\begin{array}{l}\text { Qualitative with a } \\
\text { descriptive approach }\end{array}$ & $\begin{array}{l}\text { The number of } \\
\text { informants was } 7 \\
\text { people }\end{array}$ & Interview & $\begin{array}{l}\text { The implementation of } \\
\text { prevention and control of } \\
\text { nosocomial infections is } \\
\text { carried out based on universal } \\
\text { precautions and precautions } \\
\text { based on transmission. }\end{array}$ \\
\hline
\end{tabular}




\begin{tabular}{|c|c|c|c|c|c|c|}
\hline No & Title/ Author/ Year & Research Purposes & Method/ Design & $\begin{array}{c}\text { Participants / } \\
\text { Number of } \\
\text { Samples }\end{array}$ & $\begin{array}{c}\text { Data } \\
\text { Collection }\end{array}$ & Result \\
\hline & & $\begin{array}{l}\text { Baji Makassar } \\
\text { Hospital }\end{array}$ & & & & \\
\hline 5. & $\begin{array}{l}\text { Exploration of the Obstacles } \\
\text { of the IPC Team in the } \\
\text { Implementation of Infection } \\
\text { Prevention and Control at } \\
\text { Rsud Labuang Baji Makassar } \\
\text { (Adhiwijaya et al., 2017) }\end{array}$ & $\begin{array}{l}\text { Explore the } \\
\text { constraints of the IPC } \\
\text { team in implementing } \\
\text { infection prevention } \\
\text { and control }\end{array}$ & $\begin{array}{l}\text { Qualitative with a } \\
\text { phenomenological } \\
\text { approach. }\end{array}$ & $\begin{array}{l}\text { The subjects of } \\
\text { this study were } \\
12 \text { informants }\end{array}$ & Interview & $\begin{array}{l}\text { The implementation of IPC at } \\
\text { Labuang Baji Makassar } \\
\text { Hospital is already underway. } \\
\text { The IPC team including IPCN } \\
\text { and IPCLN is involved in } \\
\text { infection prevention and } \\
\text { control. }\end{array}$ \\
\hline 6. & $\begin{array}{l}\text { Implementation of the Four } \\
\text { Pillars of the Tuberculosis } \\
\text { Infection Prevention and } \\
\text { Control Program } \\
\text { (Pitaloka \& Siyam, 2020) }\end{array}$ & $\begin{array}{l}\text { Knowing the } \\
\text { description of the } \\
\text { implementation of } \\
\text { the four pillars of the } \\
\text { IPC TB program at } \\
\text { the Bandarharjo } \\
\text { Health Center. }\end{array}$ & $\begin{array}{l}\text { Descriptive with a } \\
\text { qualitative approach }\end{array}$ & $\begin{array}{l}4 \text { main } \\
\text { informants and } 2 \\
\text { triangulation } \\
\text { informants }\end{array}$ & Interview & $\begin{array}{l}\text { The implementation of the } \\
\text { four pillars of IPC TB at } \\
\text { Bandarharjo Health Center } \\
\text { has not run optimally } \\
\text { according to standards }\end{array}$ \\
\hline 7. & $\begin{array}{l}\text { Analysis of the } \\
\text { Implementation of } \\
\text { Management of Prevention } \\
\text { and Control of Healthcare } \\
\text { Associated Infections at RSI } \\
\text { Ibnusina (Sapardi et al., } \\
\text { 2018) }\end{array}$ & $\begin{array}{l}\text { To understand more } \\
\text { deeply about the } \\
\text { implementation of } \\
\text { prevention } \\
\text { management and } \\
\text { control of Healthcare } \\
\text { Associated Infections } \\
\text { (HAIs) in Hospitals }\end{array}$ & $\begin{array}{l}\text { Descriptive with a } \\
\text { qualitative approach }\end{array}$ & $\begin{array}{l}\text { Participants were } \\
7 \text { participants }\end{array}$ & Interview & $\begin{array}{l}\text { The implementation of the } \\
\text { HAIs program is not yet } \\
\text { optimal, the implementation } \\
\text { management is not optimal, } \\
\text { the results of the } \\
\text { implementation of HAIs } \\
\text { implementation are not } \\
\text { optimal and the obstacles in } \\
\text { the implementation of HAIs } \\
\text { are not optimal. }\end{array}$ \\
\hline 8. & $\begin{array}{l}\text { Towards changing healthcare } \\
\text { workers' behaviour: a } \\
\text { qualitative study exploring } \\
\text { non-compliance through } \\
\text { appraisals of infection } \\
\text { prevention and control } \\
\text { practices }\end{array}$ & $\begin{array}{l}\text { Identify health worker } \\
\text { behaviors that } \\
\text { facilitate non- } \\
\text { compliance with IPC } \\
\text { practices, focusing on } \\
\text { how the assessment of } \\
\text { IPC tasks and social } \\
\end{array}$ & Qualitative Methods & $\begin{array}{l}\text { The final sample } \\
\text { consisted of } 10 \\
\text { doctors, } 10 \\
\text { pharmacists, } 18 \\
\text { nurses and } 1 \\
\text { midwife }\end{array}$ & Interview & $\begin{array}{l}\text { Overall, behavior is not } \\
\text { completely independent of } \\
\text { policy rules, but often } \\
\text { incorporates local normative } \\
\text { practices, individual } \\
\text { preferences and a professional } \\
\text { level of isolation. }\end{array}$ \\
\hline
\end{tabular}




\begin{tabular}{|c|c|c|c|c|c|c|}
\hline No & Title/ Author/ Year & Research Purposes & Method/ Design & $\begin{array}{c}\text { Participants / } \\
\text { Number of } \\
\text { Samples }\end{array}$ & $\begin{array}{c}\text { Data } \\
\text { Collection }\end{array}$ & Result \\
\hline & (Shah et al., 2015) & $\begin{array}{l}\text { and environmental } \\
\text { circumstances is } \\
\text { shaped and } \\
\text { influenced by non- } \\
\text { compliance behavior. }\end{array}$ & & & & \\
\hline 9. & $\begin{array}{l}\text { Implementing infection } \\
\text { prevention practices across } \\
\text { European hospitals: an in- } \\
\text { depth qualitative assessment } \\
\text { (Clack et al., 2018) }\end{array}$ & $\begin{array}{l}\text { Report an in-depth } \\
\text { investigation of key } \\
\text { constraints, } \\
\text { facilitators, and } \\
\text { contextual factors } \\
\text { relevant to } \\
\text { successfully } \\
\text { implementing this } \\
\text { strategy }\end{array}$ & Qualitative & $\begin{array}{l}\text { A total of } 129 \\
\text { interviews is } \\
\text { administration, } \\
\text { IPC and ICU } \\
\text { leadership and } \\
\text { staff }\end{array}$ & Interview & $\begin{array}{l}\text { Three meta-themes emerged } \\
\text { related to implementation } \\
\text { success: 'implementation } \\
\text { agenda', 'resources' and } \\
\text { 'boundary-spanning'. }\end{array}$ \\
\hline 10. & $\begin{array}{l}\text { Barriers and facilitators to } \\
\text { infection control at a } \\
\text { hospital in northern India: a } \\
\text { qualitative study (Barker et } \\
\text { al., 2017) }\end{array}$ & $\begin{array}{l}\text { Knowing hospital } \\
\text { infection control } \\
\text { practices, based on } \\
\text { the SEIPS conceptual } \\
\text { framework. }\end{array}$ & Qualitative & 129 respondents & Interview & $\begin{array}{l}\text { Person, task, and } \\
\text { organizational level factors are } \\
\text { the main barriers and } \\
\text { facilitators for infection } \\
\text { control in this hospital. Major } \\
\text { barriers include high nursing } \\
\text { staff turnover rates, time spent } \\
\text { training new staff, limited } \\
\text { language competence, and } \\
\text { heavy clinical workload. }\end{array}$ \\
\hline
\end{tabular}




\begin{tabular}{|c|c|c|c|c|c|c|}
\hline No & Title/ Author/ Year & Research Purposes & Method/Design & $\begin{array}{c}\text { Participants / } \\
\text { Number of } \\
\text { Samples }\end{array}$ & $\begin{array}{c}\text { Data } \\
\text { Collection }\end{array}$ & Result \\
\hline 11. & $\begin{array}{l}\text { Analysis of the } \\
\text { Implementation of the } \\
\text { Management of the } \\
\text { Healthcare Associated } \\
\text { Infections Prevention and } \\
\text { Control Committee at } \\
\text { Tugurejo Hospital, Central } \\
\text { Java Province (Agusti et al., } \\
\text { 2019) }\end{array}$ & $\begin{array}{l}\text { Analyzing the } \\
\text { management of the } \\
\text { implementation of } \\
\text { the HAIs prevention } \\
\text { and control } \\
\text { committee at } \\
\text { Tugurejo Hospital, } \\
\text { Central Java Province. }\end{array}$ & Qualitative & $\begin{array}{l}20 \text { nurses and } \\
\text { doctors }\end{array}$ & Deep interview & $\begin{array}{l}\text { IPC committee members have } \\
\text { not received training evenly, } \\
\text { there is no commitment from } \\
\text { all officers involved in the IPC } \\
\text { program, there is no incentive } \\
\text { for IPC committee members, } \\
\text { there is an unbalanced } \\
\text { workload in the IPC } \\
\text { committee members, there are } \\
\text { still shortages and delays in } \\
\text { providing IPC facilities, and } \\
\text { compliance officers on } \\
\text { handhygiene is still around } \\
80 \% \text {. }\end{array}$ \\
\hline 12. & $\begin{array}{l}\text { Human Resource Factors } \\
\text { and Management } \\
\text { Commitment Affecting } \\
\text { Surveillance of Nosocomial } \\
\text { Infection at Paru Batu } \\
\text { Hospital (Kartika S et al., } \\
\text { 2015) }\end{array}$ & $\begin{array}{l}\text { Identifying the root } \\
\text { causes of the sub- } \\
\text { optimal } \\
\text { implementation of } \\
\text { the nosocomial } \\
\text { infection surveillance } \\
\text { reporting program }\end{array}$ & Qualitative & 10 people & $\begin{array}{l}\text { Document } \\
\text { study, } \\
\text { structured } \\
\text { interviews and } \\
\text { observations. }\end{array}$ & $\begin{array}{l}\text { Lack of management support } \\
\text { for IPC support programs and } \\
\text { facilities, no socialization, and } \\
\text { no oversight function for the } \\
\text { implementation of nosocomial } \\
\text { infection surveillance } \\
\text { programs. }\end{array}$ \\
\hline 13. & $\begin{array}{l}\text { Qualitative study of views } \\
\text { and experiences of } \\
\text { performance management } \\
\text { for healthcare-associated } \\
\text { infections } \\
\text { (Brewster et al., 2016) }\end{array}$ & $\begin{array}{l}\text { Characterize the views } \\
\text { and experiences of } \\
\text { regulation and } \\
\text { performance } \\
\text { management with } \\
\text { regard to IPC. }\end{array}$ & $\begin{array}{l}\text { Qualitative } \\
\text { descriptive }\end{array}$ & 10 people & Interview & $\begin{array}{l}\text { Centrally-led performance } \\
\text { management may have several } \\
\text { important roles in IPC, but } \\
\text { identifying where it fits and } \\
\text { determining the boundaries is } \\
\text { critical. }\end{array}$ \\
\hline
\end{tabular}




\begin{tabular}{|c|c|c|c|c|c|c|}
\hline No & Title/ Author/ Year & Research Purposes & Method/Design & $\begin{array}{c}\text { Participants / } \\
\text { Number of } \\
\text { Samples }\end{array}$ & $\begin{array}{c}\text { Data } \\
\text { Collection }\end{array}$ & Result \\
\hline 14. & $\begin{array}{l}\text { The Infection Control Risk } \\
\text { Assessment and Strategies to } \\
\text { Reduce HAIs at Hospital in } \\
\text { Yogyakarta Indonesia } \\
\text { (Rosa et al., 2019) }\end{array}$ & $\begin{array}{l}\text { Analyzing Infection } \\
\text { Control Risk } \\
\text { Assessment and } \\
\text { Infection reduction } \\
\text { strategies Associated } \\
\text { with Health Care in } \\
\text { Hospitals in } \\
\text { Yogyakarta. }\end{array}$ & Qualitative & $\begin{array}{l}139 \text { health } \\
\text { workers }\end{array}$ & $\begin{array}{l}\text { Researchers } \\
\text { also collected } \\
\text { data using in- } \\
\text { depth } \\
\text { interviews and } \\
\text { document } \\
\text { reviews. }\end{array}$ & $\begin{array}{l}\text { The strategy for reducing HAI } \\
\text { is taken by breaking the chain } \\
\text { of infection, identifying } \\
\text { bacteria using HAI, using } \\
\text { rational antibiotics, optimizing } \\
\text { surveillance of HAI, carrying } \\
\text { out regular regular meetings, } \\
\text { reporting, cooperating, } \\
\text { evaluating, socializing, } \\
\text { monitoring and preventing, } \\
\text { strengthening SOPs ( Standard } \\
\text { Operating Procedures) for HAI } \\
\text { types. }\end{array}$ \\
\hline
\end{tabular}


This section is a mapping result based on research questions. Based on the mapping results of 14 articles on the implementation of infection prevention and control programs for medical personnel, they are grouped into research focus and paper type categories.

\section{Research Focus}

Table 2. Research Focus

\begin{tabular}{|c|c|c|c|c|c|}
\hline No & Focus & Support & Less Support & Amount & $\%$ \\
\hline 1. & Knowledge & A1 & A12 & 2 & 4.0 \\
\hline 2. & Awareness & & A5, A7 & 2 & 4.0 \\
\hline 3. & Commitment & A1, A13 & A3 & 3 & 6.0 \\
\hline 4. & $\begin{array}{l}\text { Availability of human } \\
\text { resources }\end{array}$ & $\mathrm{A} 2, \mathrm{~A} 6, \mathrm{~A} 8$ & A7, A12, A13 & 6 & 12.0 \\
\hline 5. & Training & A6, A10 & A3 & 3 & 6.0 \\
\hline 6. & Facilities / infrastructure & $\mathrm{A} 1, \mathrm{~A} 4, \mathrm{~A} 8$ & A2, A3, A5, A6, A10 & 8 & 16.0 \\
\hline 7. & Fund & A8, A10 & $\mathrm{A} 2, \mathrm{~A} 3, \mathrm{~A} 6, \mathrm{~A} 7$ & 6 & 12.0 \\
\hline 8. & Management support & $\mathrm{A} 1, \mathrm{~A} 2, \mathrm{~A} 11$ & A7 & 4 & 8.0 \\
\hline 9. & Organizational structure & A1, A3, A11 & A8 & 4 & 8.0 \\
\hline 10. & SOP Guidelines & $\mathrm{A} 2, \mathrm{~A} 8$ & A4, A6 & 4 & 8.0 \\
\hline 11. & Evaluation & $\mathrm{A} 2, \mathrm{~A} 6$ & A3, A7, A9 & 5 & 10.0 \\
\hline 12. & Recording of cases of infection & & A3, A5, A10 & 3 & 6.0 \\
\hline & Total & & & 48 & 100,0 \\
\hline
\end{tabular}

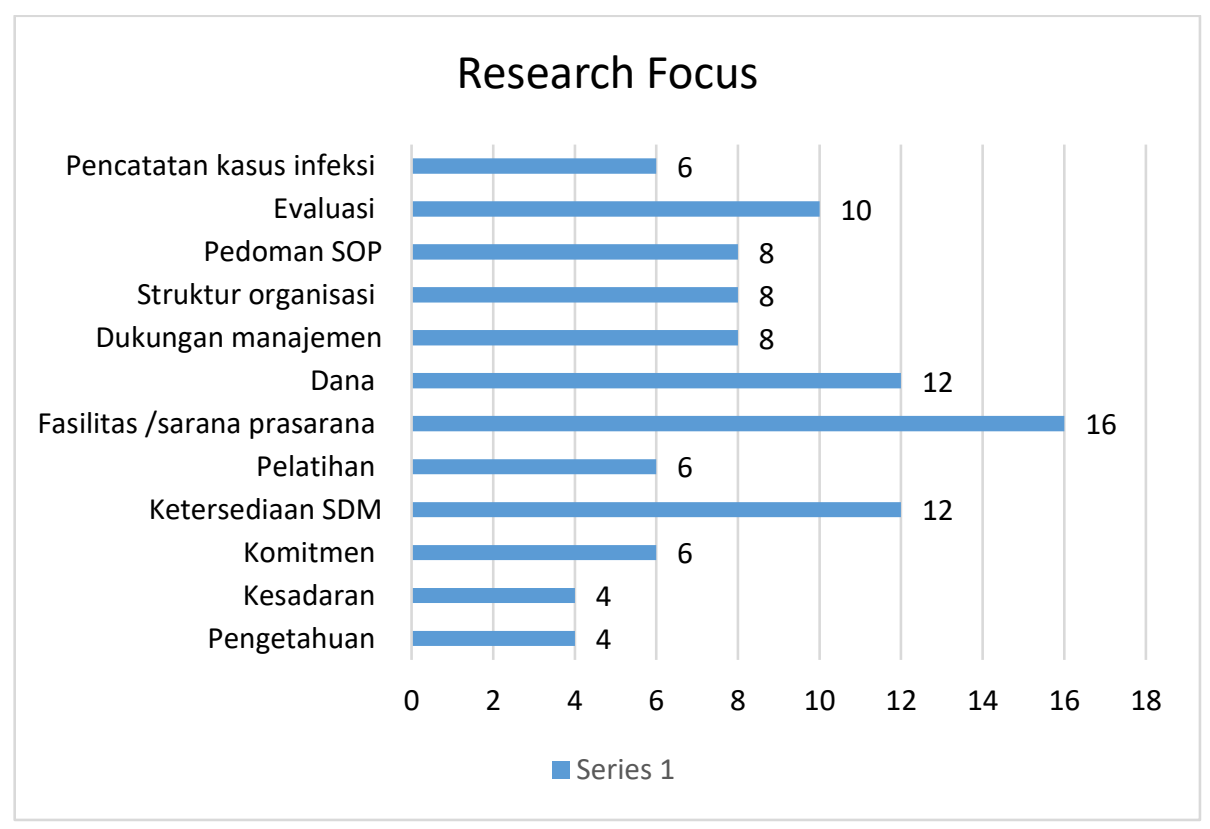

\section{Picture 1. Research Focus}

To answer the research focus, the researchers classified 14 articles in the research topic areas of research focus with the categories: Control and prevention of infection. Figure 2 is a percentage of a topic that is widely researched, namely research with a focus on knowledge, awareness, and commitment, availability of human resources, training, infrastructure, funds, management support, organizational structure, SOP guidelines, evaluation and recording of infection cases. 


\section{Publication trends in each country from time to time}

Based on the maipcng results, it was found that the trend of countries of origin of the most publications produced research on infection prevention and control, namely in the Asian Continent, namely Indonesia 10 (73.3\%), in the European Continent namely $1(6.7 \%)$ and in the UK $2(13,3 \%)$, and $1(6.7 \%)$ in India. Figure 4 is a research trend published in an electronic database starting in 2015-2020 which resulted in 14 published articles. In Figure 4, 2018-2019 is the highest research trend on the application of infection prevention and control, namely there are 4 published articles.

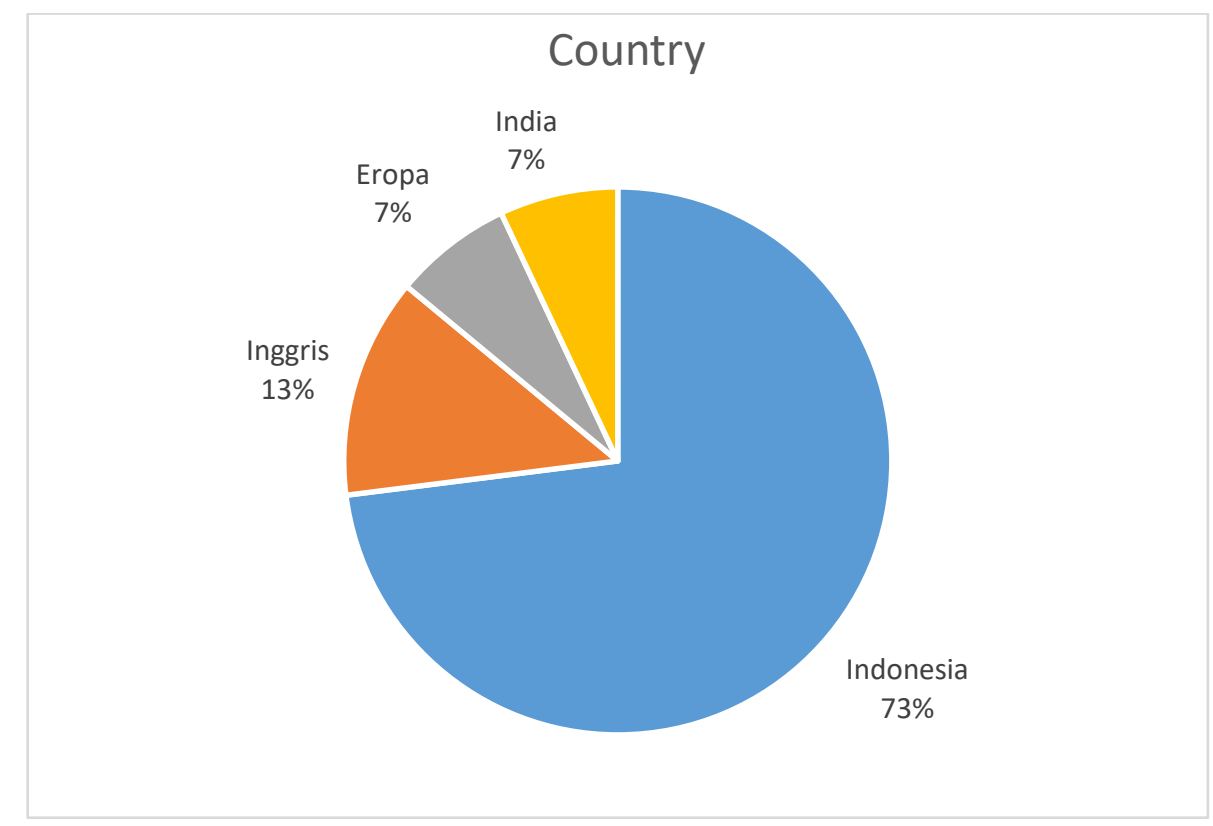

Picture 2. Trends Country of origin

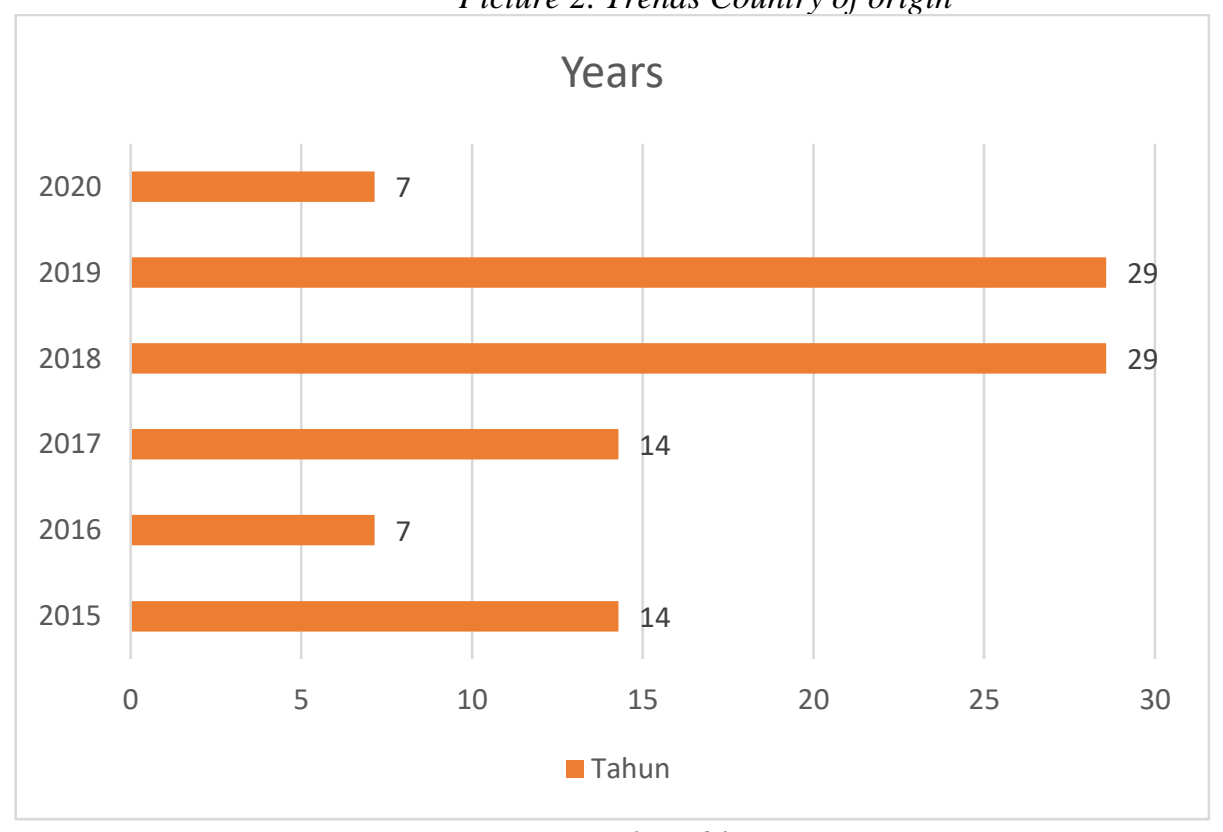

Picture 3. Publication Year

\section{Discussion}

Awareness

Human resources are the main factor which makes an important contribution to infection prevention and control. Prevention of nosocomial infections requires integration, monitoring, 
and programs from all medical personnel, including doctors, nurses, therapists, pharmacists, and others. In this literature review, there are 2 journals which show that the awareness of health workers is classified as less related to IPC.

Journal A5 stated that the majority of informants stated that health workers did not understand the work carried out by the IPC team so that job support was lacking, such as in sorting waste, many health workers did not pay attention to the signs that had been given to the trash for sorting infectious and non-infectious waste. This occurs due to different perceptions of health workers about IPCs. Several informants also said that not all officers wanted to receive the new knowledge that was given, making it difficult to convey IPC tasks (Adhiwijaya et al., 2017). Journal A7 also explains that the problem related to human resources that causes a decrease in reporting of infections in hospitals is the lack of awareness and understanding of staff about the importance of a nosocomial infection surveillance program (Kartika $S$ et al., 2015).

\section{Commitment}

Journal A1 explains that the informant is concerned about preventing infection. Implementing IPCs in hospitals is important to protect patients as well as protect nurses from infection. The informant also stated that he would always monitor, invite, and provide direct education to nurses to always carry out actions in accordance with the work procedure policies that have been set by the hospital. Officers carry out socialization again about job descriptions that will raise concern for being involved in the implementation and responsibility for the roles and duties of the IPCRS committee. The success of IPCRS requires the involvement of all parties in the hospital so that attention is needed to foster interest and concern for all hospital staff (Ginting et al., 2018).

The personal commitment of the individual influences the implementation of the IPC program, especially when in a boundary position, helping to overcome resource constraints and institutional segregation. The key to success is finding out-of-the-box influential individuals with positive attitudes towards the program to cross institutional boundaries and accelerate change. Such success, however, depends on the presence and active involvement of these individuals (Clack et al., 2018).

Successful implementation of the IPC program requires adequate human and material resources and dedicated agents of change who help make interventions an institutional priority (Clack et al., 2018). Human Factors Engineering (HFE) is in a position to support work in infection prevention and control and to improve overall health safety (Drews et al., 2019).

\section{Availability of human resources}

In the journal A7, it shows that the problem related to human resources in implementing IPC is the lack of trained IPC personnel (Kartika S et al., 2015). The main obstacle includes the high turnover rate of nursing staff, which indicates that the human resources needed are not sufficient so that it affects the workload which is felt to have direct implications for infection control practices. Both staff nurses and infection control nurses reported that staff nurses were less likely to practice infection control properly when they were busy (Barker et al., 2017). Successful implementation requires adequate human and material resources and dedicated agents of change who help make interventions an institutional priority (Clack et al., 2018). 


\section{Training}

With inhibiting factors, namely knowledge and competence, management must provide training that is able to provide support in the organization. Despite the training and availability of policies, some health workers show low adherence to IPC standard practice, while others indicate the absence of specific policies and / or discipline training. Training and awareness regarding appropriate IPC measures is highly recommended. This will lead to more effective IPC measures thereby reducing the risk of infection transmission (Khan et al., 2017).

The training is able to increase the knowledge and behavior of health workers in infection prevention and control. Training related to Infection Prevention and Control in European Countries is of great concern. The training commissioned by the European Center for Disease Prevention and Control (ECDC) in Infection Control in Europe sets the stage for the harmonization of IPC activities in Europe by producing a list of core competencies for IPC professionals. European certification for IPC and professional training will be a logical next step, which must be achieved in close collaboration between different stakeholders in Europe (Zingg et al., 2015).

IPC Committees or Teams are required to follow basic and advanced training and development of other IPC knowledge, have a certificate issued by a training institution in accordance with laws and regulations, develop themselves by attending seminars or workshops and the like, following regular and continuous technical guidance. However, there are still committee members who have not received retraining or advanced IPC training and have not extended the validity period of their training certificates. These things make no knowledge development for members and performance is not optimal (Agusti et al., 2019).

\section{Facilities}

The facilities provided at the hospital are sufficient. Provision of material and equipment facilities as an implementation of the IPC program in hospitals is always fulfilled. Reports to the director to provide the required items are always fulfilled and approved so that the warehouse for supplying the goods will provide the items needed. The provision of supporting facilities for the work of the IPC committee and team is good because there is a special room for the IPC committee (Ginting et al., 2018). More specifically, the availability of facilities and infrastructure that support the installation of infusions, changing bandages, injecting and handling waste must be good (Madjid \& Wibowo, 2017).

Many hospitals are not ready to carry out IPC, especially in facilities and infrastructure for sterilization, clean water and sewage treatment, especially for class $\mathrm{C}$ and $\mathrm{D}$ hospitals (Herman $\&$ Handayani, 2017). Lack of management support for IPC supporting programs and facilities has resulted in less optimal IPC at home (Kartika S et al., 2015). Hospital infrastructure and design are the main factors that contribute to the spread of infection in hospitals $(54.20 \%)$ (Rabaan et al., 2017).

The completeness of the means in the implementation of infection prevention and control is still incomplete and does not comply with standards. There are several facilities that are still not equipped by management, such as sinks, CSSD devices, operating sets and hand hygiene equipment (Ramayanti et al., 2019). Several other obstacles are related to the facilities and infrastructure in implementing IPC, namely the facilities and the number of hand washes and hand rubs are not sufficient and are not evenly distributed, facilities and the number of PPE are also not sufficient and are evenly distributed. Coupled with the physical buildings that are still minimal (Rismayanti, 2019). The facilities and infrastructure in the hospital are inadequate, such as plastic bags for infectious waste that are always running out, safety boxes are rarely available and limited PPE (Adhiwijaya et al., 2017). 


\section{Funding}

Funds for implementing infection prevention and control in one hospital in Indonesia are not sufficient. In the hospital's Business Plan and Budget (RBA) document, there is no specific detail regarding the allocation of funds for the implementation of IPC activities. The source of the budget comes from the Regional Public Service Agency/Badan Layanan Umum Daerah (BLUD) and Regional Government funds (Ramayanti et al., 2019). Implementation of capacity building for health workers in IPC, donation of IPC kits for health facilities and mentoring in IPC increases IPC compliance during virus outbreaks (Ousman et al., 2019).

Journal A6 states that the IPC Committee in the hospital does not have a special budget because it is a BLUD, so that it experiences difficulties when holding activities or if you want to send members for outside training and there are no allowances or incentives for officers other than IPCN causing other IPC member officers to have no commitment and motivation in program implementation (Agusti et al., 2019).

Apart from human resources, funding sources to support the success of infection prevention and control programs must also be a priority. Implementation of capacity building for health workers in IPC, IPC funding donations to support health and mentoring in IPC (Ousman et al., 2019). A considerable amount of funds / budget is expected to support the implementation of IPC activities, a budget for disinfectants, PPE, and IPC training and the availability of a special IPCN room (Ramayanti et al., 2019).

Funds are needed to improve the smooth running of infection prevention and control programs. As the literature study reveals that the economic challenges in the use of infection prevention and control programs, including variable utility in infection prevention and control, lack of controlled trials, and difficulties in modeling infectious diseases in general, future economic evaluation studies seek to be consistent with these guidelines. published for economic evaluation (Rennert-May et al., 2018).

\section{Management support}

The director with the structural ranks of the hospital has made plans to form an IPC organization as a preparation for hospital accreditation, then the director with the structural ranks has formed a committee and an IPC team at the hospital. To elect several employees and to become chair of the IPC / IPCO, IPCN and IPCLN committees. Employees who have been elected are given a decree which is binding as a member of the IPC committee and is immediately submitted to each committee (Ginting et al., 2018).

Problems related to the lack of support and management commitment to the IPC program include the decree of the appointment of the IPC committee and the IPC team so that the implementation is not optimal, there is no allocation of funds so that the implementation of work programs related to infrastructure, there is no regular monitoring and evaluation and no feedback from management related to infection reporting (Kartika $S$ et al., 2015).

\section{Organizational structure}

From the results of the interview, it shows that the Royal Prima Hospital has formed an IPC committee which is directly responsible to the director in order to reduce the number of infections that occur in hospitals with the aim of preventing and controlling infections. The informant also informed that the IPC organizational structure already consists of the Chair of the IPC / IPCO committee. The IPC team consists of 4 IPCN and IPCLN in each inpatient room (Ginting et al., 2018). The A3 study also explained that in the hospital there are already IPC Committees and Teams where the IPC Committee consists of a chairperson, secretary and 
members who are representatives of units related to IPC. The IPC team consists of, the secretary of the Infection Prevention Control Nurse (IPCN), and members of the Infection Prevention Control Link Nurse (IPCLN). However, this committee has not yet been legalized because there is no decree signed by the Director of the Hospital (Ramayanti et al., 2019).

\section{SOP Guidelines}

The hospital already has a good hospital policy, it can be shown by the availability of SOPs that support the implementation of the IPC program (Madjid \& Wibowo, 2017). Policies related to the organizational structure in the IPC program are important. One of them is the IPCLN (Infection Prevention Control and Link Nurse) as the implementer of the IPC program in the hospital, which is expected to become an "opinion leader" to motivate all employees and visitors in terms of infection control. The IPCLN that has been selected by management must be based on the level of ability, education and have a leadership spirit (Mustariningrum, 2015).

The availability of SOPs that support the implementation of the IPC program is able to contribute to the implementation of IPC (Madjid \& Wibowo, 2017). Functionally, the organization of the hospital infection prevention and control committee is under the hospital director. The IPC committee should consist of several people from various disciplines. The committee must be media officers who have received basic hospital infection education and training and received Infection training (Rismayanti, 2019).

\section{Evaluation}

The description of the supervisory duties by IPCN has gone well, while the supervisory duties by IPCLN have not been optimal due to the many tasks and responsibilities that must be carried out and the absence of special incentives or benefits given to IPCLN (Ginting et al., 2018). To maximize the prevention and control of HCAI and MDRO in Europe, surveillance should be further increased by targeting infections related to relevant health services. The role of feedback should be explored in more detail (Hansen et al., 2018). Transmission of infection can be avoided by using infection control practices. A well-managed surveillance methodology is required based on CDC guidelines (Khan et al., 2015).

Achieving service goals and higher quality results, the hospital needs to make efforts to improve the implementation of infection prevention and control programs, monitor and evaluate, look for problems related to IPC and find solutions to these problems (Ramayanti et al., 2019).

Three ways in which health workers assess their behavior are identified through accounts of IPC policies and practices: 1) attribution of responsibility, with ambiguity about responsibility for a particular IPC practice; 2) risk prioritization and assessment, which shows the different values inherent in several IPC policies and practices; and 3) the hierarchy of influence highlights that traditional clinical roles challenge work relationships (Shah et al., 2015).

\section{Recording of infection cases}

Recording and reporting in manual form is one of the problems in IPCRS (Ramayanti et al., 2019). A qualitative study in one hospital in Indonesia revealed that recording incidents of infection was sometimes not recorded in a form that was prepared by the IPC team, so that there were several incidents not recorded in that form (Adhiwijaya et al., 2017). Recording and reporting of HAIs in hospitals that have been carried out has not been maximized, this has met the existing minimum service standards, the expected output from the implementation of good HAIs control management is in accordance with the minimum hospital service standards, 
namely the availability of HAIs recording and reporting activities. it has been going well (Sapardi et al., 2018).

\section{CONCLUSION}

The implementation of infection prevention and control programs can be influenced by several factors, including in terms of health workers who lack knowledge, awareness and commitment of the importance of IPC while providing health services. The lack of human resources is also able to hamper the performance of medical personnel in implementing infection prevention and control programs. However, the support from management such as providing training to medical personnel can be a driving factor. The less than optimal funding factor and the insufficient availability of facilities and infrastructure in the IPC program can hinder the success of IPC in hospitals. This means that human resource factors and other supporting factors contribute to the application of IPC so as to reduce the incidence of infection. A successful IPC program will have an impact on increasing universal precaution as an indicator of the success output of the IPC program.

The implications of this study is mapped the existing infection prevention and control application literature by searching for articles from scientific literature databases. This was done to provide an overview of the existing literature on the application of infection prevention and control for further research in order to easily evaluate how efforts can be made to maximize the application of infection prevention and control. This study applies the SLR (systematic literature review) to determine what focus has been studied in this area of research. From the results of 14 research articles that have been mapped systematically, we classify research articles based on a research method approach with the topics discussed, namely: the application of infection prevention and control with a research focus on knowledge, awareness, commitment, availability of human resources, training, infrastructure, funds, management support, organizational structure, SOP guidelines, evaluation and recording of infection cases. The research method adopted by SLR is a practical research method to identify the right topics to research, as well as which areas are needed for more systematic research. The results of this study can provide guidance in helping researchers to plan future research through the discovery of research gaps (Research Gaps).

This review has limitations. First, the study reports in the final analysis come mainly from various regions with developed and developing economic status, and thus, there may be gaps. Second, publication bias may exist because we only examined scientific data sources and the search was limited to one database in English and one Indonesian. Third, surveillance studies are primarily descriptive qualitative in nature. Thus, data on outcome indicators are limited.

Suggestions in this study is medical personnel should be able to increase understanding regarding the importance of the PPI program so that the implementation of health service activities can be provided optimally and help overcome the problem of spreading infection. Hospitals or health facilities should be able to provide facilities and infrastructure that support the IPC program and provide funds to complement the PPI infrastructure and provide training for medical personnel in the hospital. The implementation of PPI is also expected to run well with careful planning, a clear organizational structure and regular supervision of the implementation of PPI. For further researchers, they can conduct further research on both internal and external factors that affect the success of the PPI program, especially external factors such as patients and their families, which currently has not been done much research. 


\section{REFERENCE}

Adegboye, M. B., Zakari, S., Ahmed, B. A., \& Olufemi, G. H. (2018). Knowledge, awareness and practice of infection control by health care workers in the intensive care units of a tertiary hospital in Nigeria. African Health Sciences, 18(1), 72. https://doi.org/10.4314/ahs.v18i1.11

Adhiwijaya, A., Sjattar, E. L., \& Natsir, R. (2017). Eksplorasi Kendala Tim Ppi Dalam Pelaksanaan Pencegahan Dan Pengendalian Infeksi Di Rsud Labuang Baji Makassar. Jurnal Ilmiah Kesehatan Diagnosis, 11(4), 6.

Agusti, Y. K., Suryoputro, A., \& Kusumastuti, W. (2019). Analisis Pelaksanaan Manajemen Komite Pencegahan Dan Pengendalian Healthcare Associated Infections di RSUD Tugurejo Provinsi Jawa Tengah. Media Kesehatan Masyarakat Indonesia, 18(4), 7.

Barker, A. K., Brown, K., Siraj, D., Ahsan, M., Sengupta, S., \& Safdar, N. (2017). Barriers and facilitators to infection control at a hospital in northern India: A qualitative study. Antimicrobial Resistance \& Infection Control, 6(1), 35. https://doi.org/10.1186/s13756-017-0189-9

Beyamo, A., Dodicho, T., \& Facha, W. (2019). Compliance with standard precaution practices and associated factors among health care workers in Dawuro Zone, South West Ethiopia, cross sectional study. BMC Health Services Research, 19(1), 381. https://doi.org/10.1186/s12913019-4172-4

Birgand, G., Johansson, A., Szilagyi, E., \& Lucet, J.-C. (2015). Overcoming the obstacles of implementing infection prevention and control guidelines. Clinical Microbiology and Infection, 21(12), 1067-1071. https://doi.org/10.1016/j.cmi.2015.09.005

Brewster, L., Tarrant, C., \& Dixon-Woods, M. (2016). Qualitative study of views and experiences of performance management for healthcare-associated infections. Journal of Hospital Infection, 94(1), 41-47. https://doi.org/10.1016/j.jhin.2016.01.021

Clack, L., Zingg, W., Saint, S., Casillas, A., Touveneau, S., da Liberdade Jantarada, F., Willi, U., van der Kooi, T., Damschroder, L. J., Forman, J. H., Harrod, M., Krein, S., Pittet, D., \& Sax, H. (2018). Implementing infection prevention practices across European hospitals: An in-depth qualitative assessment. BMJ Quality \& Safety, 27(10), 771-780. https://doi.org/10.1136/bmjqs2017-007675

Damanik, S. M., Susilaningsih, F. S., \& Amrullah, A. A. (2012). Kepatuhan Hand Hygiene Di Rumah Sakit Immanuel Bandung. Students E-Journal, 1(1), 29.

De Carvalho Nagliate, P., Nogueira, P. C., De Godoy, S., Amélia, I., \& Mendes, C. (2013). Measures of knowledge about standard precautions: A literature review in nursing. Nurse Education in Practice, 13, 244-249. https://doi.org/10.1016/j.nepr.2013.02.011

Drews, F. A., Visnovsky, L. C., \& Mayer, J. (2019). Human Factors Engineering Contributions to Infection Prevention and Control. Human Factors: The Journal of the Human Factors and Ergonomics Society, 61(5), 693-701. https://doi.org/10.1177/0018720819833214

Fayaz, S. H., Higuchi, M., Hirosawa, T., Sarker, M. A. B., Djabbarova, Z., \& Hamajima, N. (2015). Knowledge And Practice Of Universal Precautions Among Health Care Workers In Four National Hospitals In Kabul, Afghanistan. The Journal of Infection in Developing Countries, 8(04), 535-542. https://doi.org/10.3855/jidc.4143

Ginting, C. N., Nasution, S. W., Khu, A., \& Panggabean, D. D. (2018). Implementasi Program Pencegahan dan Pengendalian Infeksi di RS Umum Royal Prima Tahun 2018. Scientia Journal, $7(2), 9$.

Hansen, S., Schwab, F., Zingg, W., Gastmeier, P., \& the PROHIBIT study group. (2018). Process and outcome indicators for infection control and prevention in European acute care hospitals in 2011 to 2012 - Results of the PROHIBIT study. Eurosurveillance, 23(21). https://doi.org/10.2807/1560-7917.ES.2018.23.21.1700513 
Herman, M. J., \& Handayani, R. S. (2017). Sarana dan Prasarana Rumah Sakit Pemerintah dalam Upaya Pencegahan dan Pengendalian Infeksi di Indonesia. Jurnal Kefarmasian Indonesia, 6(2), 137146. https://doi.org/10.22435/jki.v6i2.6230.137-146

Kartika S, Y., Hariyanti, T., \& Pujiastuti, L. (2015). Faktor Sumber Daya Manusia dan Komitmen Manajemen yang Mempengaruhi Surveillance Infeksi Nosokomial di Rumah Sakit Paru Batu. Jurnal Kedokteran Brawijaya, 28(2), 181-185. https://doi.org/10.21776/ub.jkb.2015.028.02.12

Khan, H. A., Ahmad, A., \& Mehboob, R. (2015). Nosocomial infections and their control strategies. Asian Pacific Journal of Tropical Biomedicine, 5(7), 509-514. https://doi.org/10.1016/j.apjtb.2015.05.001

Khan, H. A., Baig, F. K., \& Mehboob, R. (2017). Nosocomial Infections: Epidemiology, Prevention, Control and Surveillance. Asian Pacific Journal of Tropical Biomedicine, 7(5), 478-482. https://doi.org/10.1016/j.apjtb.2017.01.019

Kitchenham, B., \& Charters, S. (2007). Guidelines for Performing Systematic Literature Reviews in Software Engineering, Technical Report EBSE 2007-001. Keele University and Durham University Joint Report.

Madjid, T., \& Wibowo, A. (2017). Analisis Penerapan Program Pencegahan dan Pengendalian Infeksi di Ruang Rawat Inap RSUD Tebet Tahun 2017. 4, 12.

Massinga, Z. E. (2016). Compliance with universal precautions in Northern Kwa-Zulu Natal operating theatres. Occupational Health Southern Africa, 22(2), 150.

Mustariningrum, D. L. T. (2015). Kinerja IPCLN dalam Pencegahan dan Pengendalian Infeksi di Rumah Sakit: Peran Pelatihan, Motivasi Kerja dan Supervisi. Jurnal Aplikasi Manajemen, 13(4), 10.

Nugraheni, R., Suhartono, \& Winarni, S. (2012). Infeksi Nosokomial di RSUD Setjonegoro Kabupaten Wonosobo. Media Kesehatan Masyarakat Indonesia, 11(1), 7.

Ousman, K., Kabego, L., Talisuna, A., Diaz, J., Mbuyi, J., Houndjo, B., Ngandu, J.-P., Omba, G., Aruna, A., Mossoko, M., Djingarey, M. H., Balde, T., Abok, P., Diallo, B., Dovlo, D., Yao, M., Fortin, A., Formenty, P., \& Fall, I. S. (2019). The impact of Infection Prevention and control (IPC) bundle implementation on IPC compliance during the Ebola virus outbreak in Mbandaka/Democratic Republic of the Congo: A before and after design. BMJ Open, 9(9), e029717. https://doi.org/10.1136/bmjopen-2019-029717

Pitaloka, W., \& Siyam, N. (2020). Penerapan Empat Pilar Program Pencegahan dan Pengendalian Infeksi Tuberkulosis Paru. HIGEIA, 4(1), 13.

Pratami, H. A., Apriliana, E., \& Rukmono, P. (2013). Identifikasi Mikroorganisme Pada Tangan Tenaga Medis dan Paramedis di Unit Perinatologi Rumah Sakit Abdul Moeloek Bandar Lampung. Medical Journal Of Lampung University, 85-94.

Rabaan, A. A., Alhani, H. M., Bazzi, A. M., \& Al-Ahmed, S. H. (2017). Questionnaire-based analysis of infection prevention and control in healthcare facilities in Saudi Arabia in regards to Middle East Respiratory Syndrome. Journal of Infection and Public Health, 10(5), 548-563. https://doi.org/10.1016/j.jiph.2016.11.008

Ramayanti, Semiarty, R., \& Lestari, Y. (2019). Analisis Pelaksanaan Program Pencegahan dan Pengendalian Infeksi Nosokomial di RSUD Pasaman Barat (Standar Akreditasi Versi 2012). Jurnal Kesehatan Andalas, 8(3), 10.

Rennert-May, E., Conly, J., Leal, J., Smith, S., \& Manns, B. (2018). Economic evaluations and their use in infection prevention and control: A narrative review. Antimicrobial Resistance \& Infection Control, 7(1), 31. https://doi.org/10.1186/s13756-018-0327-z 
Rismayanti, M. (2019). Gambaran Pelaksanaan Program Pencegahan dan Pengendalian Infeksi Di Rumah Sakit Umum X Kota Y. Jurnal Kesehatan Andalas, 8(1), 9.

Rosa, E. M., Listiowati, E., \& Sari, N. (2019). The Infection Control Risk Assessment and Strategies to Reduce HAIs at Hospital in Yogyakarta Indonesia. Asian Social Work Journal, 4(2), 14.

Rosaliya, Y., Suryani, M., \& Shoribun. (2012). Faktor-Faktor Yang Mempengaruhi Kejadian Infeksi Nosokomial Pada Pasien Luka Post Operasi Di Rsud Tugurejo Semarang. Karya Tulis Ilmiah STIKES Telogorejo, 1, 10.

Sapardi, V. S., Machmud, R., \& Gusty, R. P. (2018). Analisis Pelaksanaan Manajemen Pencegahan dan Pengendalian Healthcare Associated Infections di RSI Ibnusina. Jurnal Endurance, 3(2), 9.

Shah, N., Castro-Sánchez, E., Charani, E., Drumright, L. N., \& Holmes, A. H. (2015). Towards changing healthcare workers' behaviour: A qualitative study exploring non-compliance through appraisals of infection prevention and control practices. Journal of Hospital Infection, 90(2), 126-134. https://doi.org/10.1016/j.jhin.2015.01.023

Sugiyono. (2010). Statistika Untuk Penelitian. Alvabeta.

Syahrir, S., Tirmanidhana, F., Raodhah, S., \& Bujawati, E. (2018). Analisis Pelaksanaan Pencegahan dan Pengendalian Infeksi Nosokomial Di ICU RSUD Labuang Baji Makassar. 4(2), 7.

WHO. (2007). Standard Precautions in Health Care.

Zingg, W., Mutters, N. T., Harbarth, S., \& Friedrich, A. W. (2015). Education in infection control: A need for European certification. Clinical Microbiology and Infection, 21(12), 1052-1056. https://doi.org/10.1016/j.cmi.2015.09.001 